\title{
ISTO NÃO É UMA PERSONAGEM \\ O processo de Anna Karasińska
}

\author{
ESTO NO ES UN PERSONAJE \\ El proceso de Anna Karasińska
}

\section{THIS IS NOT A CHARACTER \\ The process of Anna Karasińska}

\author{
Patrícia Teles Sobreira de Souza ${ }^{1}$
}

\begin{abstract}
RESUMO
O estudo aborda o procedimento de criação cênica desenvolvido pela diretora polonesa, Anna Karasińska, durante a residência artística realizada no TEMPO FESTIVAL (2018). A pesquisa visa uma reflexão sobre o 'processo' de Karasińska, termo que utiliza para definir sua práxis, assim como uma análise dos mecanismos de produção adotados pela artista cujo trabalho fundamenta-se na presença cênica.

PALAVRAS-CHAVE: presença, representação, teatro.
\end{abstract}

\section{RESUMEN}

El estudio aborda el procedimiento de creación escénica desarrollado por la directora polaca, Anna Karasińska, durante la residencia artística realizada en el TIEMPO FESTIVAL (2018). La investigación busca una reflexión sobre el 'proceso' de Karasińska, término que utiliza para definir su praxis, así como un análisis de los mecanismos de producción adoptados por la artista cuyo trabajo se fundamenta en la presencia escénica.

Palabras clave: presencia, representación, teatro.

\section{ABSTRACT}

The study explores the scenic creation procedure developed for the polish director, Anna Karasinska, during the artistic residency held at TEMPO FESTIVAL (2018). The research aims at a reflection on the 'process' of Karasińska, term that she uses to define her praxis, as well as an analysis of the production mechanisms adopted by the artist whose work is based on the scenic presence.

KEYWORDS: presence, representation, theater.

$$
* * *
$$

Em 2015, Anna Karasińska estreou no teatro com a direção da peça Ewelina's Crying (Ewelina Chora), montagem realizada pelo TR Warszawa em Varsóvia. A diretora polonesa possui formação em cinema e filosofia e,

1 Doutoranda do Programa de Pós-graduação em Arte da Universidade de Brasília e bolsista da CAPES; E-mail: patriciateles86@gmail.com. 
apesar dos poucos anos dedicados à direção teatral, destacou-se na área por 'desenferrujar' a práxis teatral contemporânea e pelo caráter criativo de suas produções. Em Ewelina Chora, Anna promove um dinâmico jogo de linguagem, no qual, três atores renomados na Polônia representam atores amadores que, por sua vez, representam os atores consagrados. Em outras palavras, os renomados Adam Woronowicz, Maria Maj e Rafael Máckowiak, representam atores inexperientes representando a eles mesmos.

The actors taking part in the production attempt to play themselves as imagined by someone else. Other people's visions and fantasies are brought to bear on the performers' true selves. Unable to rebut what is being said about them, they remain stuck in their arbitrary and incomplete representations. As a result of this multiplicity of roles it is hard to say who is actually saying the lines spoken on stage. ${ }^{2}$ (TR WARSZAWA, 2015).

Neste imbricamento de camadas entre referente e significante, um quarto elemento rompe com a narrativa apresentada pelos demais. A atriz que dá o nome ao trabalho, Ewelina Pankowska, é a única do elenco que não representa uma pessoa que representa a ela mesma. Ewelina se anuncia em cena como alguém que deve figurar outra atriz: Magdalena Cielecka, uma artista célebre na Polônia. O contraponto de Ewelina é fundamental para o desenvolvimento do texto cênico, pois é sua presença que articula o contraste no jogo. No palco, somente Ewelina não se enquadra na função de representar a si mesma por meio do 'filtro', da outridade, o que promove o ruído simbólico na tessitura poética da obra.

Em meio a essa dinâmica polissêmica, Anna articula o essencial para a cena: nenhum cenário, palco italiano, poucos recursos de iluminação, figurinos cotidianos, um microfone e marcas feitas com fita crepe no chão para sinalizar o lugar onde os atores devem se posicionar (fig.1). As demarcações são grandes e, portanto, vistas pelo público, o que revela a ironia da artista em jogar com as especificidades do teatro para desconstruílo. A caixa preta está aberta e estabelece a quebra da ilusão, qualidade

\footnotetext{
2 Os atores que participam da produção tentam interpretar a si mesmos como imaginados por outra pessoa. As visões e fantasias de terceiros são trazidas para o verdadeiro eu dos intérpretes. Incapaz de refutar o que está sendo dito sobre eles, os atores permanecem presos em suas representações arbitrárias e incompletas. Como resultado dessa multiplicidade de papéis, é difícil dizer quem está realmente dizendo as falas no palco. (Tradução nossa). Release de Ewelina Chora. Disponível em: http://trwarszawa.pl/en/spektakle/ewelinas-crying/ Consultado em 16 nov.2018.
} 
eminente da cena contemporânea: "Se o teatro deve oferecer uma verdade, precisa então se dar a reconhecer e se expor como ficção e em seu processo de produção de ficções, em vez de enganar a esse respeito" (LEHMANN, 2007, p. 176).

A complexidade da obra reside na presença dos atores e na narrativa criada por Anna com base no material 'coletado' durante os ensaios. O procedimento de criação da cena se dá por meio do working in progress, portanto, valoriza o caráter experimental e o processo de montagem em detrimento de uma lógica cartesiana que prioriza o 'produto final acabado'.

A criação pelo working in progress opera-se através de redes de leitmotive, da superposição de estruturas, de procedimentos gerativos, da hibridação de conteúdos, em que o processo, o risco, a permeação, o entremeio criador-obra, a iteratividade de construção e a possibilidade de incorporação de acontecimentos de percurso são as ontologias da linguagem (COHEN, 2006, p.1).

O leitmotiv de Ewelina Chora surge a partir do trabalho processual de Anna. A diretora relata que ensaiou com não-atores e que a partir desse laboratório desenvolveu a poética para a montagem da peça. Somente no estágio final de ensaios que o elenco entrou no processo, neste momento, o repertório coletado a partir da vivência com os não-atores foi transformado e reinventado no corpo dos quatro atuantes profissionais.

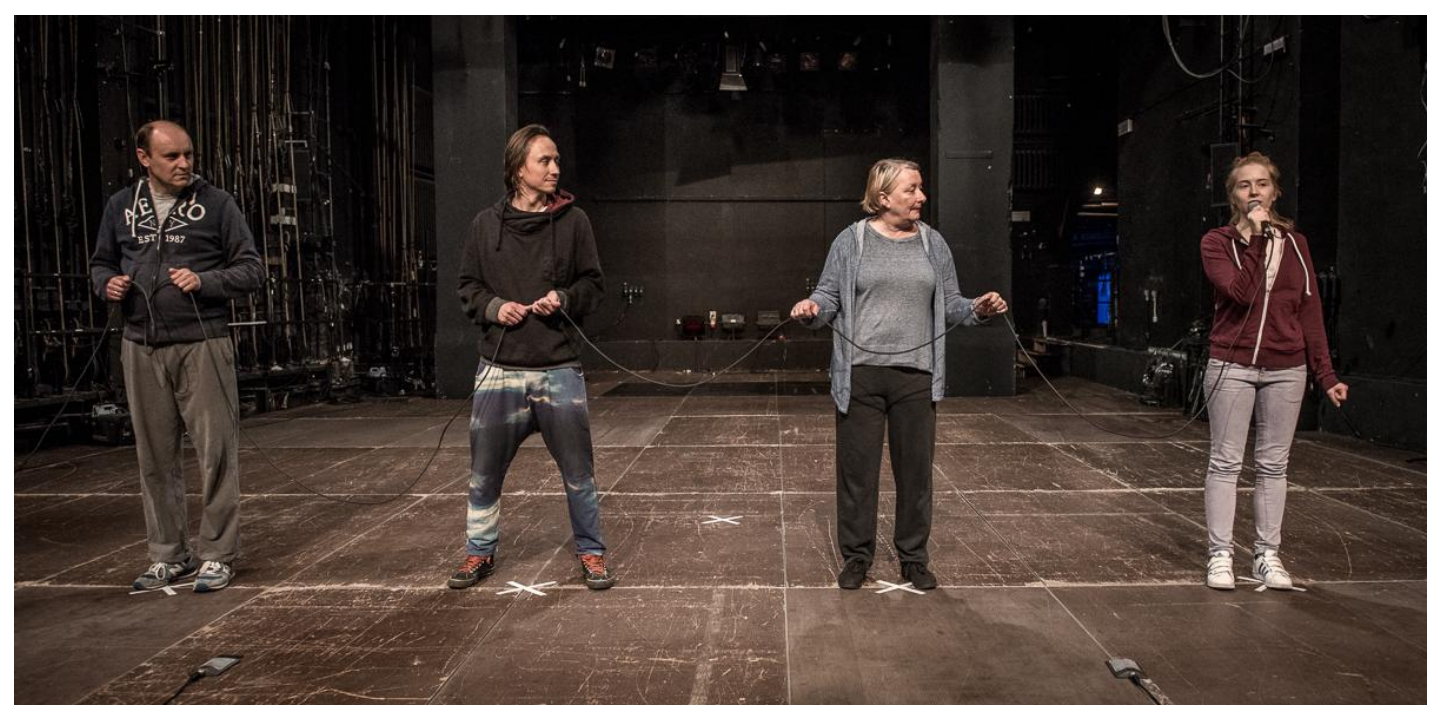

Figura 1 - Ewelina Chora (2015), direção: Anna Karasińska Fonte: http://trwarszawa.pl/en/spektakle/ewelinas-crying/

Karasińska promove um giro na linguagem que remete a ideia de 'representação' sem cair no contexto aristotélico demímesis. Para além do 
'papel' que cada um representa, o trabalho dos atores está fundamentado na presença. Deste modo, o objetivo não é ser o mais verosímil possível, mas de apresentar uma situação, na qual diluísse a ideia de interpretação de uma personagem em virtude do jogo de representação, onde as camadas de significação estão abertas ao espectador. $O$ jogo fundamenta-se principalmente por meio da linguagem verbal, a partir do anunciado do significante, por exemplo, se uma atriz verbaliza que é uma cobra, o código com o espectador está estabelecido. Ao ver a atriz em cena, o público saberá que ela representa uma cobra, apenas por sua presença, sem a necessidade de execução de movimentos corporais ou ruídos que remetam ao animal.

Neste âmbito, representar é significar, e com este giro Karasińska transcende a questões antimiméticas assumidas como propriedades do teatro contemporâneo. Segundo Lehmann (2007), “o signo central do teatro, o corpo do ator, recusa o papel de significante" (p.157), o autor afirma que o corpo se absolutiza na medida em que o teatro pós-dramático se afasta de uma 'estrutura mental inteligível', "uma vez que o corpo não expõe nada além de si mesmo, a renúncia a significação pelo corpo e a orientação para um corpo de gestos destituídos de sentido" (p.158). Neste contexto, Lehmann observa a partir dos anos 1970 a emergência de uma prática cênica que rompe com o modelo de teatro dramático. Dentre o modus operandi desse 'novo teatro', está a dissolução da ideia de 'personagem'.

Contudo, para além da construção da personagem e do atorperformer, que não representa nada para além de si mesmo, o teatro contemporâneo se desdobra em variáveis múltiplas que trabalha a significação do corpo pela metalinguagem. A esse respeito, Fèral (2015) afirma que no teatro performativo, "o ator apare aí, antes de tudo, como um performer. Seu jogo, seu corpo, suas competências técnicas são colocadas na frente" (p.120). Segundo a autora, "o performer instala a ambiguidade de significações, os deslocamentos dos códigos, os deslizes de sentido. Trata-se, portanto, de desconstruir a realidade, os signos, os sentidos e a linguagem" (p.122). Nessa conjuntura encontra-se o trabalho de Karasińska, que desconstrói e reorganiza os signos teatrais por meio da presença dos atores 
como significantes, mas que contrapõem-se ao conceito clássico de representação assim como ao completo esvaziamento de sentido.

Em Ewelina Chora, os atores são corpos presentes no aqui-agora do acontecimento teatral que utilizam da teatralidade, da desarticulação dos códigos e das convenções do teatro para mostrar como representam uma situação. Camadas de sentido são sobrepostas neste jogo semântico no qual os espectadores são cúmplices dos artifícios de representação dos atores. A potência criativa de Karasińska reside, entre outros fatores, na valorização da 'presença' sem rechaçar ou anular as possibilidades da representação. Trata-se, portanto, de emancipar a representação, de pensá-la para além do caráter ilusório de tentativa de reprodução da 'realidade', mas, por outro lado,

que, ao invés de reunir, de modo estático, signos ou um metatexto, o considere enquanto um processo dinâmico que acontece no curso do tempo e que é efetivamente produzido pelo ator, (...) Constatamos hoje uma emancipação gradual dos elementos da representação teatral e observamos uma mudança estrutural: a renúncia à unidade orgânica ordenada a priori e o reconhecimento do fato teatral enquanto polifonia significante, aberta para o espectador (DORT, 2013, p.50-51).

Em 2016, Karasińska apresentou Ewelina Chora no TEMPO FESTIVAL (Festival Internacional de Artes Cênicas do Rio de Janeiro) e em outubro de 2018 retornou ao Rio de Janeiro para ministrar sua residência artística na Sede das Cias. Para este projeto, Anna selecionou dez artistas cênicos brasileiros que participaram dos dez dias de imersão: Carlos Bruno, Catarina Romano, Gabriela Carrillo, Guilherme Martins, Hugo Souza, Ismael Queiroz, Juliana França, Kali Ôza, Laura Nielsen e Patrícia Teles. Além dos selecionados, Tracy Segal participou da residência como tradutora e colaborada. A chamada para seleção de artistas destacou o caráter experimental da investigação, ressaltou que haveria uma apresentação aberta ao público no final da imersão e que não havia nenhum texto ou temática pré-estabelecida pela diretora.

Inicialmente o processo de Karasińska se desenvolveu por meio de extensivas conversas, nas quais pudemos comunicar nossas inquietações e reflexões sobre temas históricos e pessoais: colonização, escravidão, sexualidade, preconceitos, identidade, entre outros. Já nos primeiros dias de 
processo a política surgiu como uma possível vertente da pesquisa. A residência artística ocorreu no período de campanha eleitoral para o segundo turno, momento de conflitos, divergências e de grande mobilização nas ruas. Portanto, a política parecia um mote óbvio e recorrente, porém foi recebida positivamente pela maioria dos integrantes do grupo que destacaram a urgência do assunto.

Particularmente fui reticente, considerei o tema pouco frutífero devido ao desgaste nas redes sociais, nas ruas e no convívio familiar que os brasileiros enfrentaram intensamente. Ademais, todos nós concordávamos e estávamos fortemente convictos da nossa escolha política, o que me preocupou em tornar nossa apresentação do processo em uma manifestação panfletária que atingiria apenas as pessoas que concordavam com nosso discurso. Não obstante, o desafio de abordar um tema tão maçante a partir de um ponto de vista criativo e singular me manteve conectada ao processo. Anna a todo momento demonstrou-se ciente dos riscos que implicariam suas escolhas, inclusive destacando seu lugar de fala como estrangeira europeia.

Posteriormente, Karasińska introduziu no grupo outro acontecimento recente: o incêndio que destruiu o Museu Nacional na Quinta da Boa Vista. Novamente um tema atual e específico do Brasil, de grande repercussão na mídia nacional e internacional, gatilho para debates múltiplos: memória, preservação, privatização, precariedade, patrimônio, etc. Uma de suas preocupações primordiais era o modo como um tópico poderia ser abordado, como descamar o pensamento para livrar-se das obviedades (que de modo geral surgem em uma primeira aproximação a uma ideia) e penetrar uma esfera mais densa e fértil de possibilidades poéticas para a cena. 


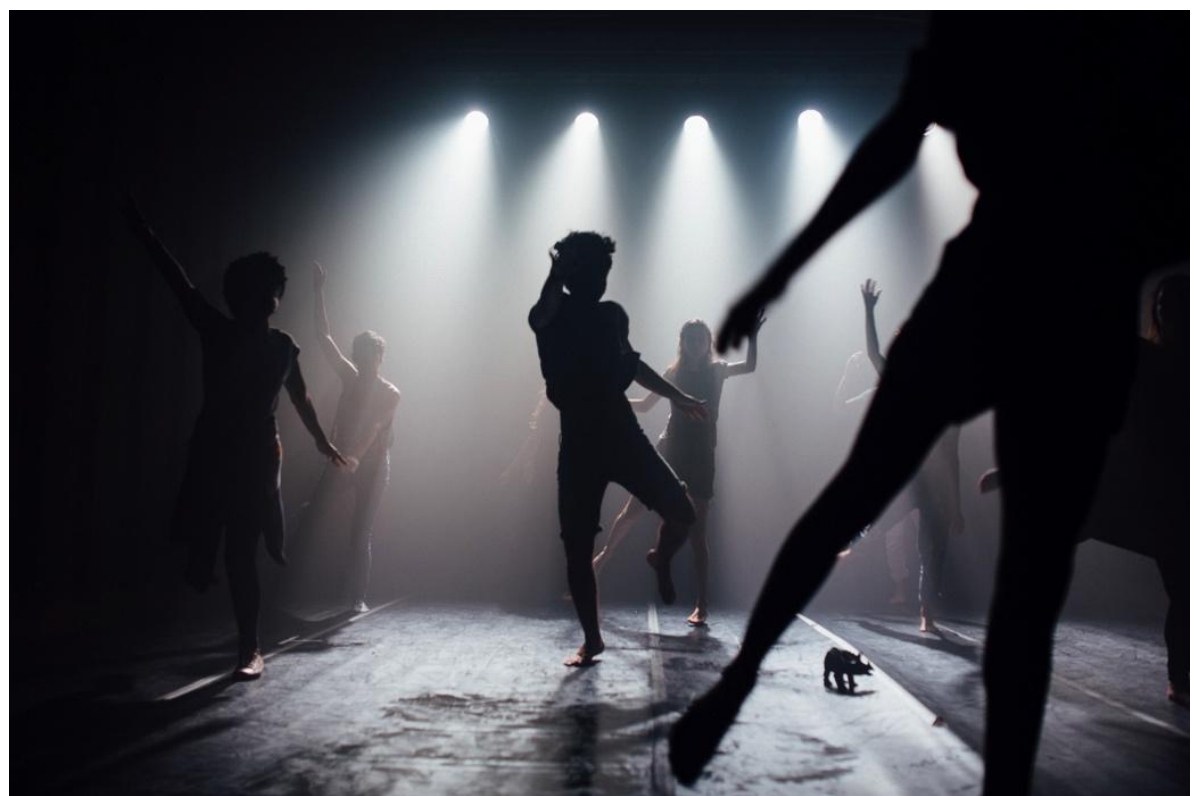

Figura 2 - Apresentação do Processo - Residência Artística com Anna Karasińska (2018) Foto: Elisa Mendes

À vista disso, uma das estratégias adotadas por Anna era a proposição de exercícios práticos, nos dez dias de residência artística realizamos distintas atividades que auxiliaram na estruturação da montagem:

- Exercício de Frases: no dia seguinte à nossa longa conversa sobre as eleições, Anna solicitou que escrevêssemos frases sobre a vivência do dia anterior. Apontamentos que não estivessem diretamente relacionadas ao evento político, como ações realizadas, frases que foram faladas (podendo ser inventadas) a partir do que foi dito, o estado do corpo naquele momento. Como, por exemplo:

- $\quad$ Eu digo o que penso.

- Vamos fugir? Ir para Espanha!

- Estou ficando sem voz.

- Minha bunda dói de tanto ficar sentada.

- Impaciente, dizíamos todos a mesma coisa com palavras diferentes.

- Lembrei que amanhã é dia de acordar cedo e fazer faxina na cozinha.

- Algumas pessoas levantam e saem da roda, sem se justificar nem pedir licença. Isso me incomoda muito.

- Não consigo dormir pensando no nosso terrível futuro.

- Agora essa posição também está doendo a minha bunda.

- Sinto-me impotente.

- Desculpe, mas não tem a ver com opinião, é fato. 
O objetivo era alcançar outros modos de nos aproximarmos do tema, no lugar de pensar uma apresentação teatral que versa sobre política, pensar uma montagem cujo tema são artistas que falam, ou tentam falar, sobre política. Um pequeno giro conceitual que transforma toda a relação com a cena. Posteriormente, Anna montou um 'quebra-cabeça' com as frases para que fossem ditas sem uma sequência lógica ou linear, mas o material engessado no papel perdeu seu frescor no corpo, e, portanto, foi descartado.

- Exercício de Mentiras: em uma folha de papel escrevemos mentiras sobre o Brasil. Novamente uma proposta para produção de material poético e um exercício para deslocar o pensamento para outros contextos menos evidentes. Surgiram sentenças baseadas em fatos e personagens históricos, estereótipos, fakenews, entre outros:

- Zumbi dos Palmares assinou a Lei Áurea.

- Pedro Álvares Cabral descobriu o Brasil.

- O aborto é legal.

- Não existe racismo no Brasil.

- Somos todos veganos.

- É absolutamente normal andar nu na rua. O Brasil é a primeira nação naturista do mundo.

- Brasil e Venezuela tornaram-se uma única nação.

- Colonizamos Plutão.

- Exercício de Partituras: deveríamos pensar e escrever os sete momentos mais marcantes da nossa trajetória como artistas, trabalhos que realizamos e que foram importantes no nosso desenvolvimento profissional. Em seguida, Anna solicitou que descartássemos dois momentos descritos, visando chegar as cinco experiências mais intensas de cada um. O exercício foi realizado individualmente, sem que tomássemos conhecimento do conteúdo dos demais. A última etapa consistia em criar uma partitura a partir da narrativa que desenvolvemos no papel. O resultado foram composições corporais abstratas e outras mais atreladas ao sentido do texto.

- Exercício de Receitas: neste exercício inventamos indagações sobre como teria sido nossa apresentação, supondo que o evento já havia ocorrido e que não tínhamos consciência de como sucedeu. As indicações 
eram as seguintes: pessoa A escreve as perguntas, $\mathrm{B}$ as responde e $\mathrm{C}$ cria uma 'receita' para cada pergunta e resposta desenvolvida.

A - O que os atores representavam? Como estavam vestidos?

B - Representavam o público, vestimentas variadas.

$\mathrm{C}$ - Tire sua roupa e troque-a com quem você quiser.

A - Qual o momento mais emocionante, o clímax da peça?

$\mathrm{B}$ - Os atores filmando os pés do público, e o público filmando o olhar dos atores. Como um processo de passagem.

C - Fale com o público: este é o clímax, estamos no clímax, a partir de agora tudo é clímax.

O conceito da 'receita' é que seja uma indicação para a cena, uma descrição de como um ou mais atores deveriam agir. Não obstante, o exercício acabou por levar outro rumo, de modo que a maioria das receitas criadas foram o roteiro de uma encenação.

A - Caiu um meteoro no palco?

B - Caiu, mas não fomos extintos. Eu (Juliana) quebrei o dente.

C - Um som muito alto de explosão. Todos os atores caem no chão ao mesmo tempo. Desabam. Logo depois vão se levantando. Juliana percebe que tem algo estranho no seu dente. Toca o próprio dente. Mostra o dente para plateia.

De modo geral surgiram roteiros herméticos e absurdos, mas essa errônea interpretação do exercício culminou no prólogo da nossa apresentação, na qual Anna criou motes para que narrássemos para o público, todos juntos, versões improvisadas de roteiros possíveis para nossa montagem. O Improviso deveria obedecer a seguinte estrutura:

Inicia com:

Então:

A plateia é:

Termina com:

Os enunciados não necessariamente deveriam ser ditos em cena, eles operavam como um código dos atores para desenvolver o jogo. Ademais dos ensaios com o elenco, Anna trabalhou exaustivamente o conteúdo do texto cênico, atualizando-o constantemente.

Ou é uma peça sobre política.

No início, represento que digo o que penso.

Então eu digo o que penso.

Então eu digo o que penso.

Então eu digo o que penso.

Ela apenas diz o que pensa. 
Você não acabou de dizer o que disse antes?

Eu tenho a impressão de que não sabemos o que estamos falando.

Ismael está esperando o momento de dizer o Manifesto do Pau Brasil que ele sabe de cor.

Este momento será muito tocante.

Juliana apenas disse que não conhece sua própria origem.

Por que começamos está conversa?

Ela termina com todo mundo brigando.

- Exercício do Mito da Vida (Life Myth): Anna nos explicou que era um exercício de psicologia e pediu para que lembrássemos da nossa memória mais antiga ou de um sonho recorrente de infância. Com uma caneta dividimos uma folha A4 em seis partes, como feito para criação de uma história em quadrinhos. Nos primeiros quatro quadrinhos desenhamos o que nós lembrávamos dessa primeira memória de vida, o desenrolar dessa história. No quinto o que gostaríamos que tivesse ocorrido, e, por fim, no sexto quadrinho desenhamos um final da história no tempo presente, ou seja, como adultos.

Em seguida escolhemos algumas palavras para adjetivar nosso 'mito da vida': medo, solidão, calor, desapego, euforia, confusão, entre outros. O passo seguinte consistia em circular uma palavra e cruzar outra, essas duas palavras representam nossos polos opostos. A primeira base ou o ponto superficial, é a palavra circulada que representa o modo como vemos a nós mesmos. Já a palavra cruzada é a base mais profunda, que revela traços sonegados da nossa relação com o mundo.

Por meio desse exercício, Anna teve acesso as nossas memórias íntimas que serviram como matéria prima para construção de algumas cenas. O material coletado foi transformado pela direção para compor o acervo poético do Museu que estávamos construindo. O exemplo mais marcante foi da atriz Catarina, que em seus quadrinhos revelou que sua primeira lembrança de infância era ter visto um gnomo em seu quarto e ter chamado seu tio para constatar a presença desse ser mitológico. No contexto do Museu, Catarina era a pessoa que estabelecia o contato com o invisível, a que podia enxergar o que ninguém mais via. Portanto, sua cena consistia em apresentar a 'sala de coisas invisíveis': 
Essa é a sala cheia de coisas invisíveis.

Porque isto é um teatro e porque toda sala é um museu de coisas invisíveis.

É bom, porque sendo invisíveis, não podem ser queimadas.

Você reconhece isso? E aquilo? Mesmo que você não queira ver, aquilo vem. Está aqui e aqui.

As coisas invisíveis me fazem fazer coisas.

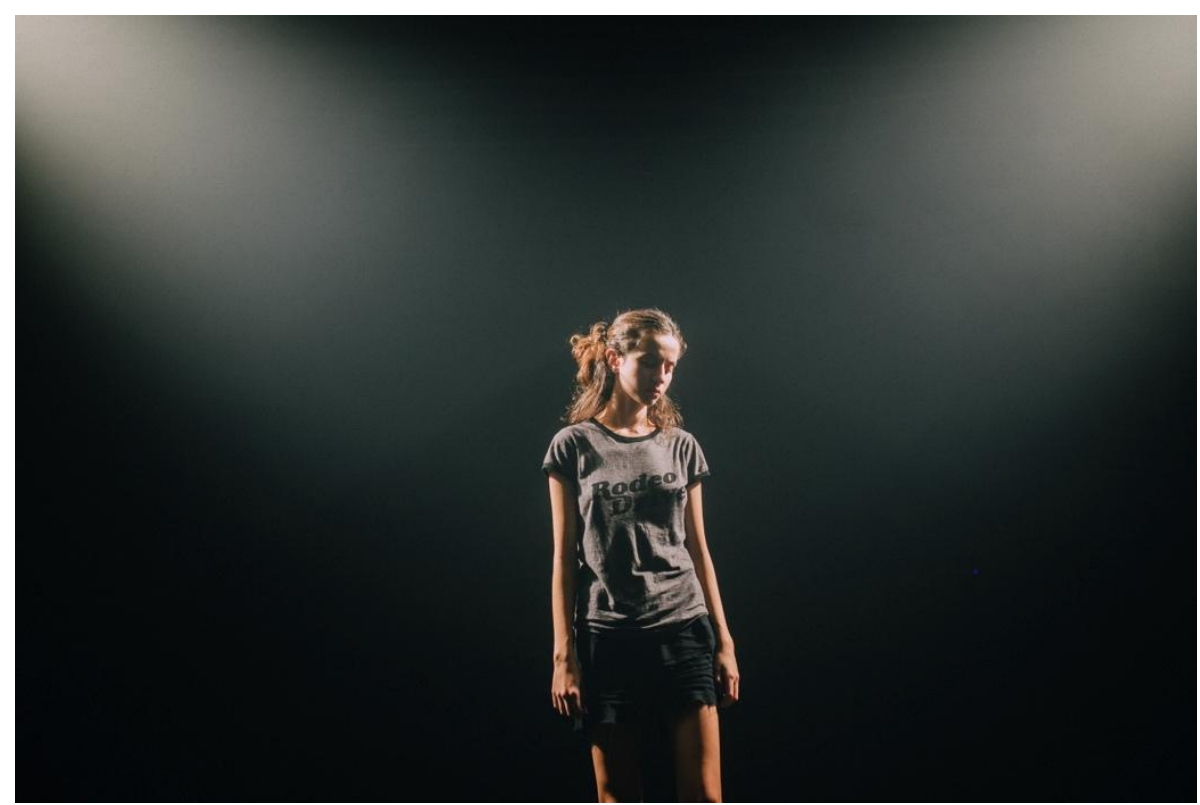

Figura 3 - Apresentação do Processo - Residência Artística com Anna Karasińska (2018) Foto: Elisa Mendes

- Exercício do Museu: cada um deveria levar um objeto-coisa do museu incendiado, tangível ou intangível, abstrato ou figurativo. Uma proposta aberta a inventividade dos participantes. Alguns pensaram em referências mais diretas: dinossauros, meteoros, máscaras indígenas ou o crânio de Luiza (fóssil humano mais antigo da América do Sul). Outros buscaram caminhos menos conectados ao universo do Museu e recorreram a esfera do íntimo.

O exercício do museu serviu de base para construção de boa parte das cenas, que foram alimentadas por materiais gerados em outras dinâmicas e lapidados pela direção. Diante do conteúdo diverso, trazidos por artistas de formações distintas, Anna logrou condensar a pluralidade de poéticas em uma massa homogênea. Deste modo, atuações dramáticas dialogavam com ações performativas, assim como cenas que faziam menção direta ao acervo do Museu Nacional foram sobrepostas a cenas de conteúdo íntimo, do acervo pessoal do performer. 
No espaço museístico, Laura apresentou réplicas de máscaras indígenas, Juliana a ausência da memória de sua mãe, Hugo encontrou o seus antepassados e Guilherme leu uma carta para eles. O contraste foi evidenciado nas cenas de Gabriela e Kali que apresentaram o incêndio. Em momentos distintos, ambas apresentações foram anunciadas ao público da seguinte maneira: 'a atriz vai mostrar alguém que vê o fogo, agora'. Gabriela surge desesperada em cena, avida por conter o incêndio, por sua vez, Kali realiza uma debochada coreografia manipulando um energético da marca Burn.

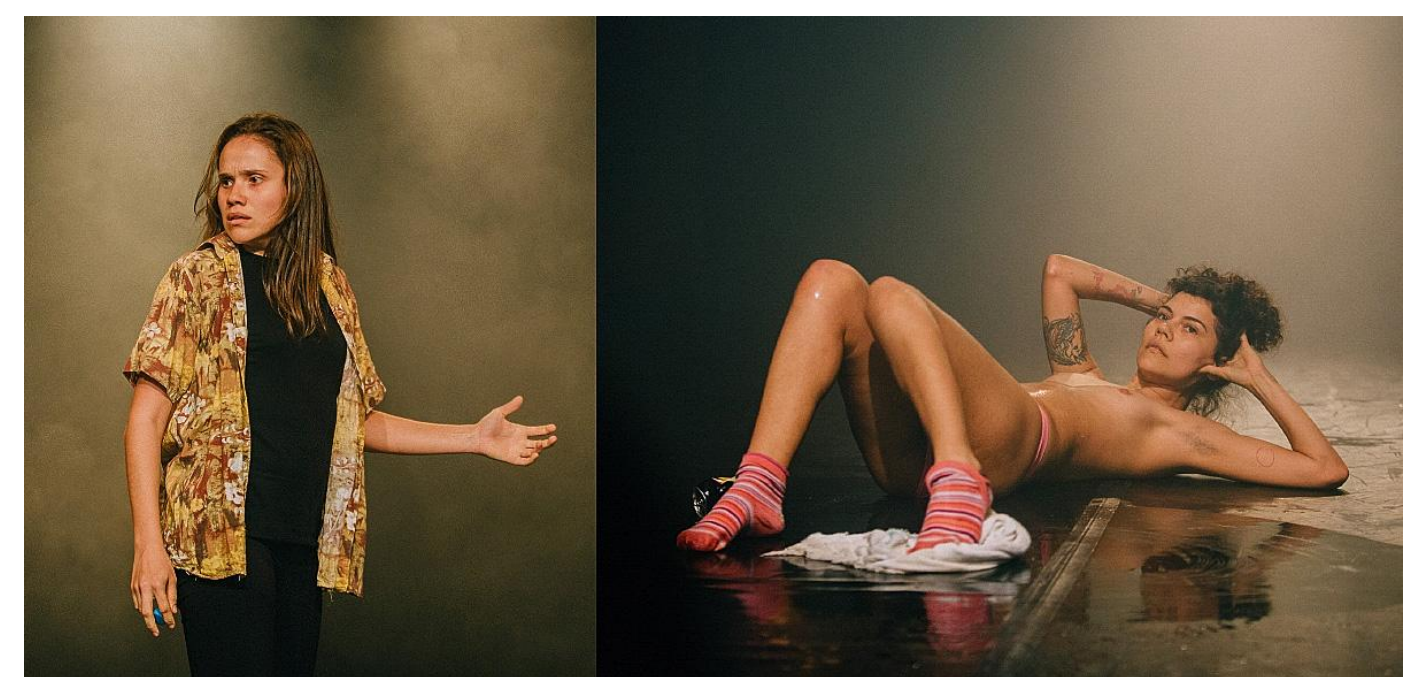

Figura 4 - Apresentação do Processo - Residência Artística com Anna Karasińska (2018) Foto: Elisa Mendes

Mais uma vez, Karasińska apropriasse dos códigos teatrais e da metalinguagem para revelar o acontecimento cênico. As ações que se desenvolvem diante do público, sem compromisso com uma linearidade narrativa, mas como uma sucessão de movimentos, de partes fragmentadas que devem ser conectadas pelo espectador a sua maneira.

- Exercício do Espaço: sem pensar muito, escolher uma especificidade do espaço e relacionar-se com ele. A luz fria, o buraco na parede, os sapatos no chão... tomar consciência do ambiente e do que, a priori, não é percebido de imediato. 
Neste exercício, recolhi minha mochila que estava em uma cadeira da plateia, tirei os objetos de dentro e os enfileirei no palco. Caneta, caderno, carteira, dinheiro, livro, moedas, casaco, lenço de papel, amendoim, chiclete, colírio, identidade, cartão do banco, cartão do metrô, adesivos de campanha eleitoral, garrafa d'água... Em seguida, busquei os pertences dos meus companheiros para fazer o mesmo, contaminando o espaço com esse inventário de objetos do cotidiano, mesclando nossos pertences até então encobertos. Deste pequeno improviso surgiu a cena final da nossa apresentação, no qual somamos ao inventário daquele 'presente' os pertences do público, os próprios espectadores e um texto:

Essa é a coleção desse momento, um inventário desse aqui e agora.

Uma composição de objetos visíveis e invisíveis que estão aqui hoje, emoldurados nessa caixa preta. Testemunhas desse encontro.

Daqui a poucos esses objetos não estão mais aqui, esses corpos vão transitar poroutros espaços, encontrar outros objetos e outros corpos, formando novas composições.

Também no futuro parte desses objetos podem ser destruídos, perdidos, roubados, queimados, esquecidos, enterrados no estômago de algum peixe, morrer de alguma doença ou serem assassinados.

Então essa mesma composição de coisas e pessoas nunca mais vai acontecer de novo, é algo totalmente único. E caso seja do desejo de vocês, vocês podem guardar esse momento.

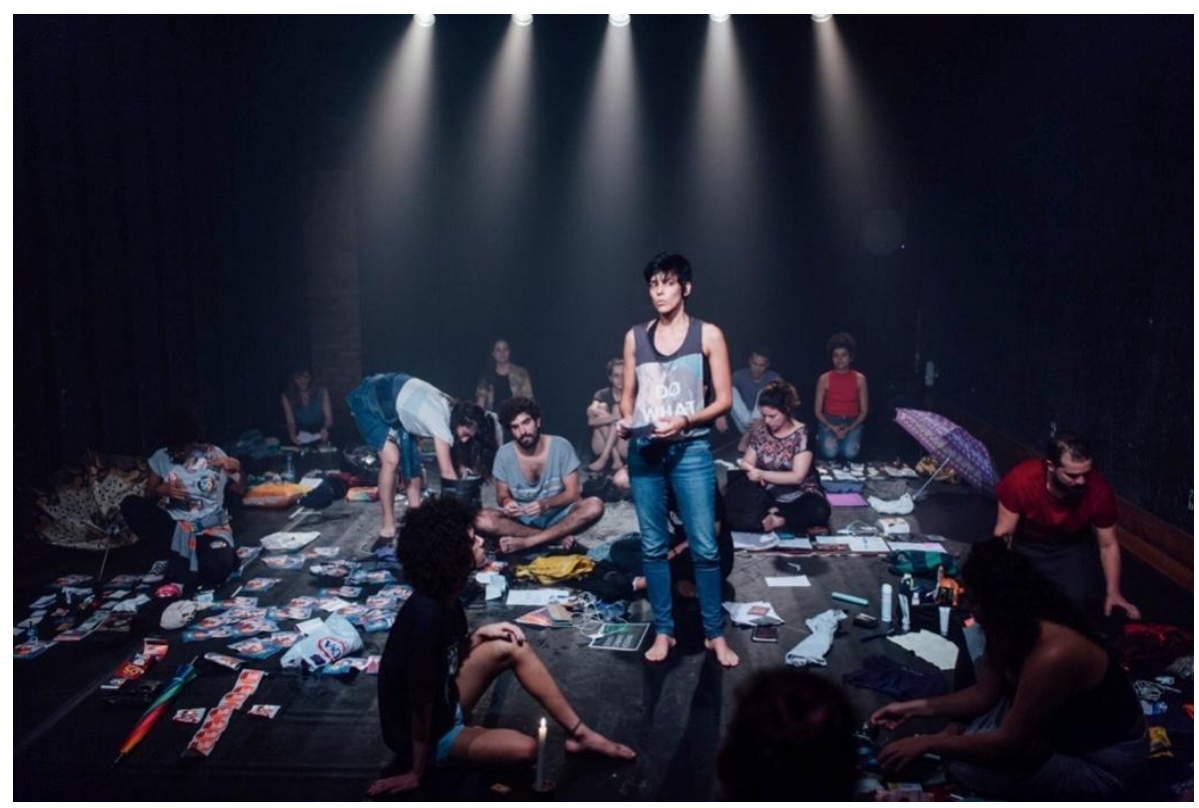

Figura 5 - Apresentação do Processo - Residência Artística com Anna Karasińska (2018) Foto: Elisa Mendes 
Cabe ressaltar que Anna não tinha um roteiro de exercícios prédefinidos para nos dirigir, boa parte de suas propostas de atividades surgiram no momento para dar conta da necessidade daquele instante. Sem fórmulas prontas, Karasińska parecia trabalhar de modo intuito, sempre atenta as peculiaridades de cada um e ao material que surgia dos improvisos, relatos, conversas e do nosso convívio durante a residência. Como na cena do Carlos, que em um de nossos encontros relatou que nunca tinha ido ao Museu Nacional.

Ele nos contou que, quando criança, costumar brincar com seu pai na Quinta da Boa Vista, mas que nunca teve vontade de entrar no Museu, que sequer sabia o que tinha lá dentro. E que, no dia anterior ao trágico incêndio, passou com seus familiares pelo sítio do Museu e que eles haviam comentado sobre visitá-lo. Em vista desse relato, Anna escreveu o monólogo de Carlos, que terminava com a seguinte afirmação:

Preciso dizer que estou representando alguém que não se interessa por cultura.

Estou muito triste por causa disso. Mas este é o meu papel.

A diretora me pediu para representá-lo e eu faço com todo o meu coração.

Ainda que sem expectativas de se chegar a um resultado, no decorrer do processo entendemos que havia matéria suficiente para compor uma montagem. A sinergia do encontro foi sentida por todos, em dez dias nos entregamos a residência de modo tão intenso e único que o tempo se relativizou. Em outras palavras, em um período curto nosso trabalho e percepção como artistas da cena foram redimensionados pelo engajamento e mergulho no processo teatral. Apesar de nossas formações, idades e vivências distintas, não houve atritos, desistências ou desafetos. Possivelmente devido a atmosfera receptiva proporcionada pela direção, Anna foi uma líder confiante, transparente e sensível a nossas singularidades.

Para encerrar, descrevo o caso da cena de Ismael, que gerou uma crise e acabou por ser desenvolvida no dia da apresentação. Durante a residência Ismael apresentou uma partitura em que se movimentava pelo espaço transformando seu estado corporal. Iniciava vestido e com um computador em mãos, teclando freneticamente; passava por um estágio do 
corpo militarizado de um soldado, com movimentos firmes e retilíneos; pela autopunição, momento em que retirava a blusa e a utilizava para golpear as costas; e por outros movimentos até chegar a figura do índio desnudo, que dançava e cantava em uma língua indígena.

$\mathrm{O}$ ator construiu uma partitura corporal que ilustrava uma narrativa, do homem contemporâneo, atravessado pelas máquinas, ao homem dominado pelo poder do Estado, o homem colonizado e catequizado até culminar no estado corporal do homem pré-colombino. Ismael apresentava destreza em suas ações, entretanto, apresar da virtuose da técnica do ator, o conflito se deu quando questionado o teor didático da ação, se a cena não estará ilustrando no lugar de mostrar e se não poderia ser recebido pelo público como uma alegoria ingênua e superficial.

No debate sobre as questões da linguagem, Anna considerou que Ismael selecionou aquele material para nos apresentar pois era algo que o afetava, e o domínio e a entrega do ator bastariam como material para cena. Não obstante, essa visão que sublinha a execução e o material trazido pelo ator - em detrimento da ilustração de uma narrativa crítica sobre fatos históricos - não estava clara, podendo gerar ruído no que pretendíamos comunicar.

Para solucionar esse impasse, Anna buscou coletar mais informações sobre a trajetória de Ismael, seu percurso profissional e suas convicções e visões enquanto artista. Nesta conversa, Ismael expôs que já interpretou um proprietário de terras e Anna apropriou-se desse dado para dar a cena de Ismael um caráter polissêmico. Ademais das dicotomias indígenafazendeiro' e 'jovem ator-personagem mais velho', Anna estabeleceu uma estrutura poética que continuou possibilitando a Ismael executar parte de sua partitura, mas de modo que o 'mostrar' sobreviesse o 'ilustrar'. A estrutura da ação deu-se da seguinte maneira:

O ator vai mostrar como é ser ele mesmo no palco.

Ele já interpretou vários personagens distintos.

Apesar de jovem, ele já fez um personagem chamado Paulo Honório, do livro São Bernardo de Graciliano Ramos.

Um fazendeiro, viúvo, de 50 anos, que matava gente para aumentar sua propriedade. 
*Ismael interpreta o fazendeiro.

Por outro lado, ele também já fez um índio que cantava e dançava para sua terra.

*Ismael interpreta o indígena.

Mas agora ele não acredita mais em 'personagens'.

Ele prefere fazer as coisas de verdade, e é por isso que ele está aqui.

Vocês acham que ele está representando alguém, porque geralmente é assim no teatro.

Mas ele não está. E a gente não sabe o que ele pode fazer agora.

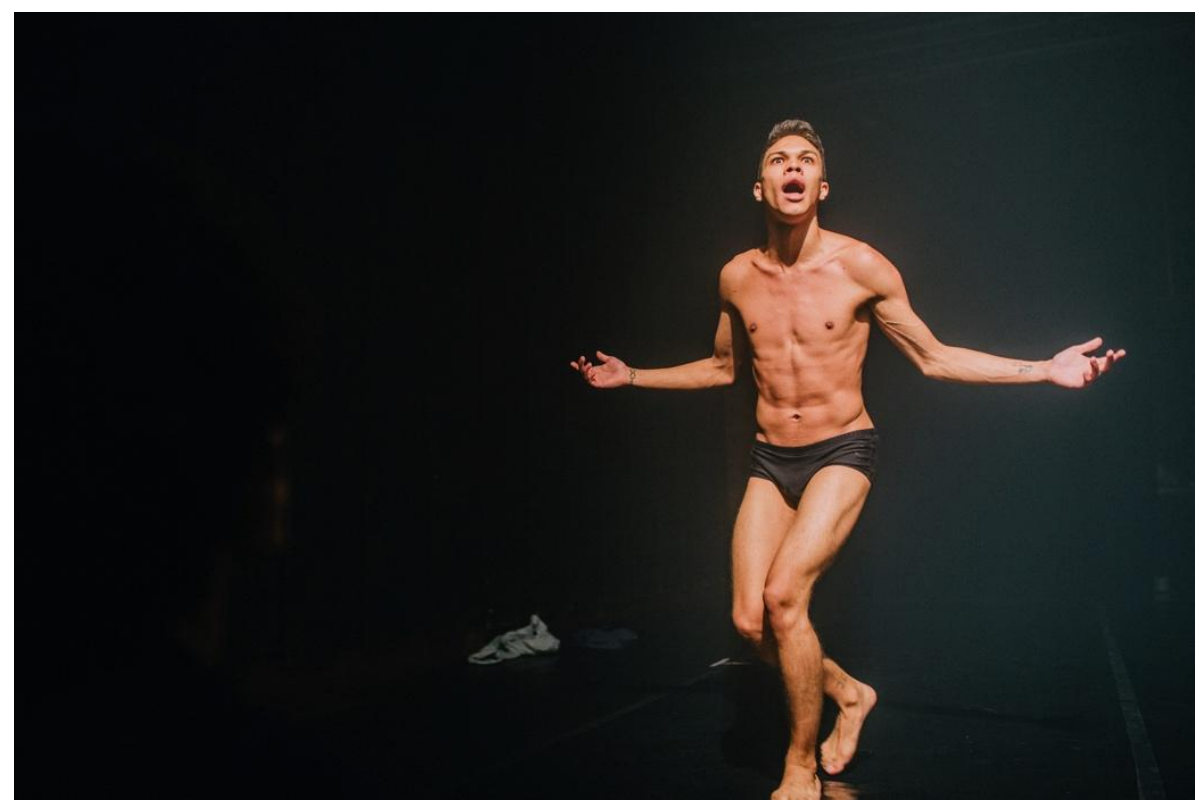

Figura 6 - Apresentação do Processo - Residência Artística com Anna Karasińska (2018) Foto: Elisa Mendes

Em conclusão, entendo o processo de Karasińska como orgânico e rizomático, pautado na escuta do outro, na horizontalidade, no diálogo e nos afetos. No que diz respeito a linguagem da cena, seu foco está na presença dos atores e atrizes-performers, na negação do óbvio e no jogo antiteatral. Pensando o antiteatral, como sinalado por Ramos (2015), como: "a repulsa a qualquer narrativa encadeada, ou, em síntese, ao dramático como estratégia instrumental para engajar o espectador" (p.33).

Apesar das insistentes afirmações de críticos e agentes teatrais - que reproduzem o discurso do, 'isto não é teatro', para deslegitimar trabalhos autorais e não convencionais - o teatro pós-dramático, ou performativo, já se consolidou como prática da contemporaneidade. "Em outras palavras, o pósdramático não é mais um termo que denota práticas desviantes, de oposição ou radicais" (LEHMANN, 2013, p.861). Assim como a performance, afastou- 
se do experimentalismo - "seja porque a experimentação se converteu no modo habitual de funcionamento da arte e se viu então dotada de uma nova legitimidade não subversiva, seja porque a experimentação simplesmente desapareceu como conceito" (FÈRAL, 2015, p.173) - e, portanto, legitimou-se e institucionalizou-se.

Agora, a indagação que surge ao observar e participar do processo de Anna diz respeito os mecanismos possíveis para evitar o engessamento do performativo, como podemos renovar e oxigenar a práxis artística para evitar o 'mais do mesmo' e germinar poéticas que desautomatizem o olhar do espectador.

$$
* * *
$$

\section{REFERÊNCIAS}

COHEN, Renato. Working in Progress na Cena Contemporânea. São Paulo: Perspectiva, 2006.

DORT, Bernard. Representação Emancipada. Revista Sala Preta, $\mathrm{n}^{0}$ 13,ECA/USP, 2013, p.47-55.

FÉRAL, Josette. Além dos Limites: teoria e prática do teatro. São Paulo: Perspectiva, 2015.

LEHMANN, Hans-Thies. Teatro Pós-dramático. São Paulo: Cosac Naify, 2007.

LEHMANN, Hans-Thies. Teatro Pós-dramático, doze anos depois. Revista Estudos da Presença, v.3, nº 3, Porto Alegre, 2013, p.859-878.

RAMOS, Luiz Fernando. Mimesis Performativa: a margem de invenção do possível. São Paulo: AnnaBlume, 2015.

Recebido em março de 2019.

Aprovado em abril de 2019.

Publicado em junho de 2019. 